\title{
ABSORPTIVE CAPACITY: COMPONENTS AND ORGANIZATIONAL MECHANISMS FOR ITS DEVELOPMENT
}

\author{
GABRIELA CAPPELLARI ${ }^{1}$ \\ (iD) https://orcid.org/0000-0003-0263-6822 \\ CLARICE V. N. WELTER ${ }^{2}$ \\ (iD) https://orcid.org/0000-0001-9684-5785 \\ LISIANE C. R. HERMES \\ (iD) https://orcid.org/0000-0002-3485-8764 \\ JORGE O. SAUSEN ${ }^{4}$ \\ (iD) https://orcid.org/0000-0003-3684-1410
}

To cite this paper: Cappellari, G., Welter, C. V. N., Hermes, L. C. R., \& Sausen, J. O. (2019). Absorptive capacity: Components and organizational mechanisms for its development. Revista de Administração Mackenzie, 20(6). doi:10.1590/1678-6971/eRAMD190028

Submission: Mar. 8, 2019. Acceptance: July 11, 2019.

1 Universidade Federal do Pampa (Unipampa), Santana do Livramento, RS, Brazil.

$2 \quad 3^{\text {a }}$ Divisão de Exército, Santa Maria, RS, Brazil.

3 Universidade de Passo Fundo (UPF), Passo Fundo, RS, Brazil.

4 Universidade Regional do Noroeste do Estado do Rio Grande do Sul (Unijuí), Ijuí, RS, Brazil.

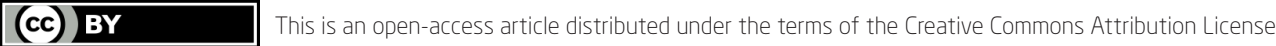

\footnotetext{
This paper may be copied, distributed, displayed, transmitted or adapted if provided, in a clear and explicit way, the name of the journal, the edition, the year and the pages on which the paper was originally published, but not suggesting that RAM endorses paper reuse. This licensing term should be made explicit in cases of reuse or distribution to third parties. It is not allowed the use for commercial purposes.

Este artigo pode ser copiado, distribuído, exibido, transmitido ou adaptado desde que citados, de forma clara e explícita, o nome da revista, a edição, o ano e as páginas nas quais o artigo foi publicado originalmente, mas sem sugerir que a RAM endosse a reutilização do artigo. Esse termo de licenciamento deve ser explicitado para os casos de reutilização ou distribuição para terceiros. Não é permitido o uso para fins comerciais.
} 


\section{ABSTRACT}

Purpose: The objective of this study is to understand how the process of absorptive capacity (ACAP) is developed, by analyzing the behaviors and abilities of a group of companies, their routines and processes and the mechanisms of learning and knowledge governance. The companies operate in the metal mechanics sector and they are based in the southern region of Brazil.

Originality/value: The relevance consists of the operationalization of component elements and in the development of organizational mechanisms of dynamic capacity (Meirelles \& Camargo, 2014), as means of ACAP development (Wang \& Ahmed, 2007) in organizations belonging to the metal mechanics sector.

Design/methodology/approach: It is a qualitative, exploratory and descriptive empirical research, carried out by a multiple case study. It seeks to investigate in detail three organizations of the metal mechanics sector, by analyzing the procedures, resources, mechanisms, and systems, which makes it possible for them to develop absorptive capacities. Content analysis was performed in order to analyze the data.

Findings: The researched companies develop absorptive capacity through some behaviors and abilities, such as relationship capacity, learning capacity, and people's training capacity, and through routines and processes, especially information search routines, market monitoring routines and risk management. Finally, the researched companies develop absorptive capacity by learning mechanisms and knowledge governance, such as researches, information exchange among clients, suppliers and other companies.

\section{KEYWORDS}

Dynamic capabilities. Absorptive capacity. Competitive advantage. Metal mechanics. Organizational mechanisms. 


\section{INTRODUCTION}

The economic outlook over the years has been increasingly complex. Progressive technological advance and globalization interfere directly in the competition among organizations. This scenario forces companies to use differentiated strategic positions, aiming to reach and sustain competitive advantage.

This study is guided by the theory of dynamic capabilities. Since Winter's (1964) proposal, many efforts have been made in order to find a concept for dynamic capabilities, especially in regard to micro-foundations and operationalization, building this way a productive field of research activities. Several authors discuss the subject, such as Collis (1994), Teece, Pisano, and Shuen (1997), Eisenhardt and Martin (2000), Zollo and Winter (2002), Winter (2003), Andreeva and Chaika (2006), Bygdas (2006), Helfat et al. (2007), Wang and Ahmed (2007), Dosi, Faillo, and Marengo (2008), McKelvie and Davidson (2009), Teece (2009), Camargo (2012), Meirelles and Camargo (2014), and Guerra, Tondolo, and Camargo (2016).

As Zollo and Winter (2002) point out, the meaning of dynamic capabilities is well-known, but how companies develop it, is still unknown. Meirelles and Camargo (2014) explain that the confluence of behaviors and skills of change and innovation, associated to support routines and processes, which are in turn backed by mechanisms of learning and knowledge governance, result in dynamic capabilities. In this regard, Guerra et al. (2016) affirm that the identification of mechanisms, in which dynamic capabilities are developed, can provide new findings over its implantation.

Wang and Ahmed (2007) identified in their research that dynamic capabilities are composed of three component elements, which are responsible for the long-term performance in organizations: adaptability, absorption, and innovation. In this regard, this study aimed to operationalize each of these elements and mechanisms pointed out by Meirelles and Camargo (2014), able to develop dynamic capabilities as a means of advancement in one of the dynamic capabilities: absorption (Wang \& Ahmed, 2007)

The concept of absorptive capacity (ACAP) has been studied since the 1980s and the 1990s and has drawn the attention of many researchers (Cohen \& Levinthal, 1990; Zahra \& George, 2002; Lane, Koka, \& Pathak, 2006; Jones, 2006; Vega-Jurado, Gutiérrez-Gracia, \& Fernándes-De-Lucio, 2008; Camisón \& Forés, 2010; Flatten, Engelen, Zahra, \& Brettel, 2011; Burcharth, Lettl, \& Ulhøi, 2015; Ferreira \& Ferreira, 2017). 
Generally, ACAP is known as an ability to identify and to amass knowledge in an external environment, by assimilating, internalizing, transforming and applying it, resulting in valuable products and services for the market (Cohen \& Levinthal, 1990; Zahra \& George, 2002; Jansen, Van Den Bosch, \& Volberda, 2005; Lane et al., 2006).

This way, we decided to investigate the development of ACAP in the sector of metal mechanics in the Rio Grande do Sul state, since inside this industry there is a highly competitive and challenging environment, with strong technological influence. It is one of the most dynamic segments of the state economy, with international repercussions (Instituto Brasileiro de Geografia e Estatística, 2016; Sindicato das Indústrias Metalúrgicas, Mecânicas e de Material Elétrico e Eletrônico do Estado do Rio Grande do Sul, 2019). The importance of the metal mechanics segment in the industry is quite considerable, along with the fact that its performance brings consequences to other economic sectors, causing this group of organizations to play an important multiplier role in the industry of Rio Grande do Sul (Breitbach, 2004).

The context in which the segment of metal mechanics is inserted is characterized as complex, uncertain and unstable by Sausen (2003). There are uncertainties and the changes become difficult to predict. It should be emphasized that companies who are part of this sector need to adapt to the contingencies and to changes in the environment, in order to ensure their survival. Therefore, it is critical for these organizations to monitor the market, to absorb the relevant information from the external environment, and to adapt organizational structures and processes in order to constantly renew, reconfigure and recreate their resources and capabilities for the sake of innovation (Majumdar, 2000; Mathiassen \& Vainio, 2007).

Considering that the reason for dynamic capabilities in organizations still requires explanations - in particular, ACAP - the objective of this study was to understand how the ACAP process is developed in companies operating in the metal mechanics sector, based in the south region of Brazil. To reach our goal, we analyzed the behaviors and abilities, the routines and processes, as well as the mechanisms of learning and knowledge governance.

The choice of studying ACAP from the perspective of dynamic capabilities, being in an ever-changing sector, is justified by the scarcity of studies relating the mechanisms and instruments to develop ACAP in organizations in this sector, and also in this region of Brazil.

The operationalization of all the elements triggering the development of ACAP in the metal mechanics sector in the aforementioned Brazilian state 
will certainly contribute to the advancement of knowledge over the microfoundations of ACAP; they are determinant for enhancing better levels of performance in organizations who play a relevant role in their own region's economy.

The study is structured in four parts, besides the introduction. In the first one, we present the bibliographic review that deals with ACAP and the component elements and organizational mechanisms for the development of this capacity. The second part presents the methodological procedures used in empirical research. Soon after, the results and, finally, the final considerations, the limitations, and suggestions for future studies.

\section{THEORETICAL FRAMEWORK}

\subsection{Absorptive capacity}

Absorptive capacity is the capacity of the organization to add new knowledge to the pre-existing ones. Cohen and Levinthal (1989, 1990, 1994) developed this theory and emphasize that ACAP is the capacity that allows the company to recognize the value of new external information, assimilating and applying it for commercial purposes.

There is a link between theory, basic skills, and learning experiences. The first ACAP model proposed by the authors covers three dimensions: recognition of information value, assimilation, and application of knowledge in order to generate innovations. The model is shown in Figure 2.1.1.

\section{(Figure 2.1.1)}

\section{COHEN AND LEVINTHAL'S ABSORPTIVE CAPACITY MODEL}

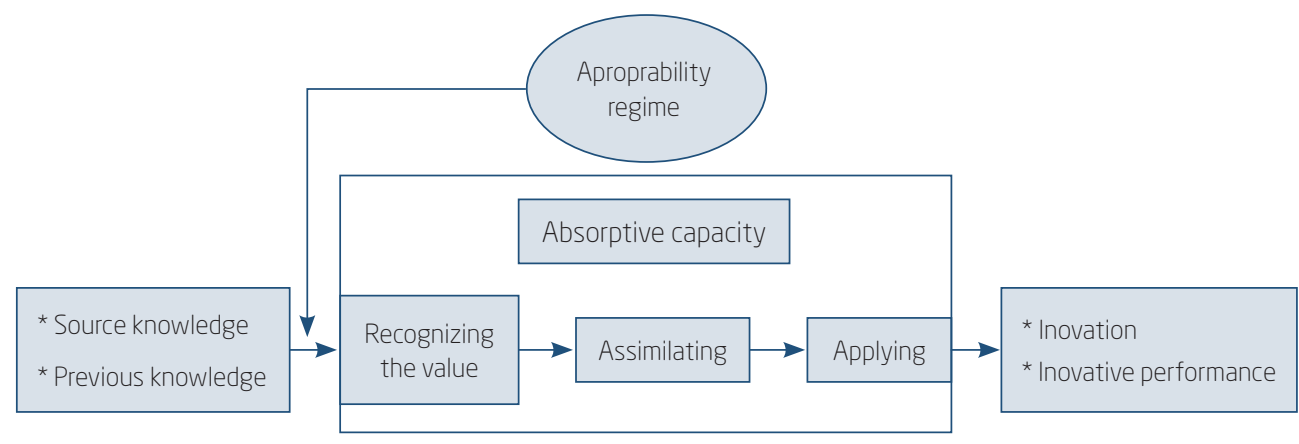

Source: Adapted from Cohen and Levinthal (1990). 
Due to the proposal of the ACAP model, Cohen and Levinthal (1990) emphasize that the development of the construct occurs through a continuous, cumulative process of knowledge acquisition and through the improvement of internal mechanisms of articulation over time. That said, an organization's absorptive capacity does not rely exclusively on the direct interface with external knowledge; it also relies on the transfer between and among the organizational units. The Appropriability regime refers to the protection of the distinctive advantages obtained and the benefits that come from it, which in turn guarantee a high level of innovative performance and the development of new products or processes, elements of sustainable competitive advantage.

From Cohen and Levinthal's definition (1989, 1990, 1994), studies attempted to diffuse the construct (Lane \& Lubatkin, 1998; Zahra \& George, 2002), which aimed to broaden the focus of ACAP beyond research and development $(\mathrm{R} \& \mathrm{D})$. Therefore, the central axis of the construct knowledge - either new or pre-existing - is the way the organization uses this resource. So the more experienced the company becomes, the easier it gets for it to find commercial applications for assimilated knowledge.

On the other hand, Zahra and George (2002) adopt a more procedural perspective in their studies and explain that the efficient distribution of internal knowledge and integration are critical elements for this capacity. According to the authors' point of view, ACAP is a set of processes and organizational routines allowing organizations to produce dynamic capacity, the basis of competitive advantage. In this conception, the authors distinguish two dimensions: ACAP potential (PACAP), comprising the capacities of acquisition and assimilation, and ACAP realized (RACAP), comprising the capacities of transformation and application. Figure 2.1.2 displays the model proposed by Zahra and George (2002).

Acquisition is the ability of valuing, identifying and acquiring external knowledge. Assimilation refers to the organizational capacity of analyzing, processing, interpreting and understanding the external information obtained. Transformation, in turn, refers to the ability of recognizing information and combining it with some existing knowledge. Finally, application refers to the ability of refining, expanding and leveraging the existing skills, in order to create new ones by incorporating the knowledge acquired (Zahra \& George, 2002).

Zahra and George (2002) also present external sources, complementarity of knowledge, and experience as antecedents of ACAP in their model. The happening of ACAP through its antecedents is conditioned by the use of 
activation triggers (external and internal events), by mechanisms of social integration (reduction of barriers in the disclosure of information) and by appropriability regimes (protection of innovation benefits). At the end, the results combine strategic flexibility, innovation, and performance as part of competitive advantage.

\section{(Figure 2.1.2)}

\section{ZAHRA E GEORGE'S ABSORPTIVE CAPACITY MODEL}

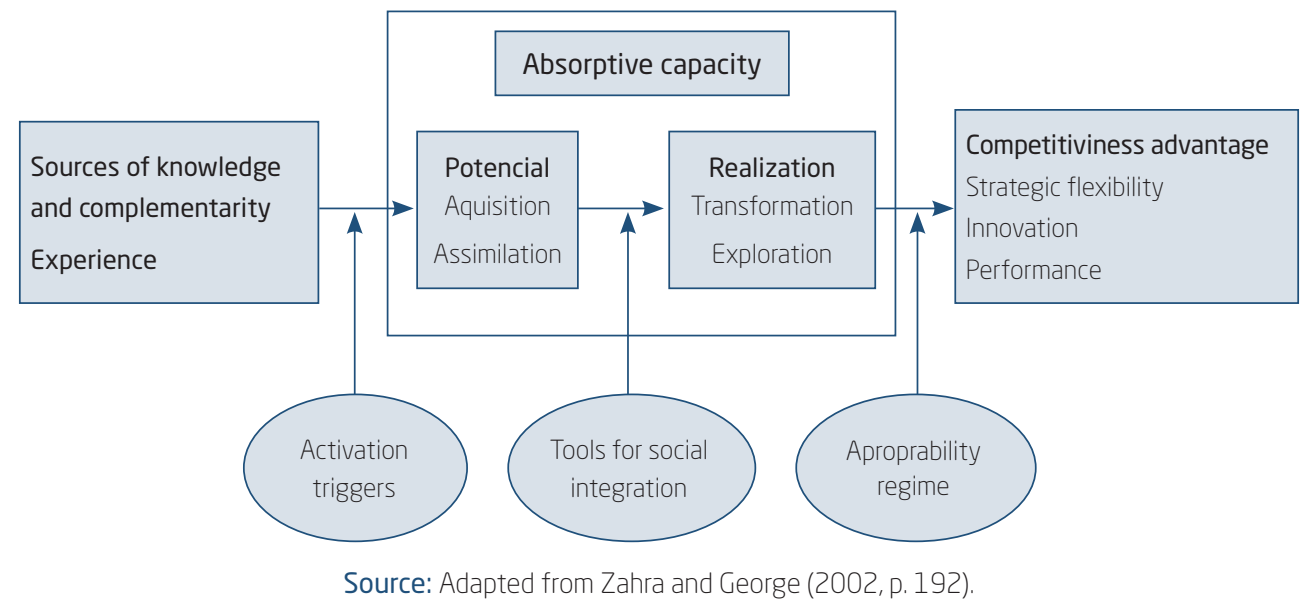

\subsection{Component elements and organizational mechanisms for the development of absorptive capacities}

Figure 2.2.1 presents the definitions of component elements and organizational mechanisms for the development of ACAP, that is, behaviors and skills of change and innovation, routines and processes of search or innovation, and mechanisms of learning and knowledge governance. 


\section{(Figure 2.2.1)}

\section{COMPONENTS AND ORGANIZATIONAL MECHANISMS FOR THE DEVELOPMENT OF ACAP}

\begin{tabular}{|c|c|}
\hline Authors & 1. Behaviors and skills for change and innovation \\
\hline \multirow[t]{2}{*}{$\begin{array}{l}\text { Andreeva and } \\
\text { Chaika (2006), } \\
\text { Teece (2009), } \\
\text { Meirelles and } \\
\text { Camargo (2014), } \\
\text { and Zollo and } \\
\text { Winter (2002) }\end{array}$} & $\begin{array}{l}\text { - Behavior is the direction and commitment to change. } \\
\text { - Behavior that emphasizes loyalty and commitment to change. } \\
\text { - The main characteristics of skills are pragmatism, tacit knowledge, and } \\
\text { choices. Pragmatism involves skills following the steps which are } \\
\text { successively triggered. Knowledge within the skills is largely unspoken, } \\
\text { that is, the actor in the performance of a certain skill is not aware of the } \\
\text { details of his performance. Also, skills encompass choices, which are in its } \\
\text { majority, automatically selected. } \\
\text { - The skills include: 1. identifying and capitalizing market opportunities as } \\
\text { well as recognizing the value of external information, assimilating it and } \\
\text { applying it commercially; } 2 \text {. quickly developing new strategies, even better } \\
\text { than the competition, and learning how to learn; 3. non-specific skills, not } \\
\text { necessarily connected to the execution of the operational routine, such } \\
\text { as: communication, negotiation, conflict resolution, leadership, economic } \\
\text { analysis of ideas, problem solving, project and people's management. }\end{array}$ \\
\hline & 2. Routines and search processes or innovation \\
\hline $\begin{array}{l}\text { Nelson (2009), } \\
\text { Teece (2009), } \\
\text { Gerard (2011), } \\
\text { Camargo (2012), } \\
\text { and Meirelles and } \\
\text { Camargo (2014) }\end{array}$ & $\begin{array}{l}\text { - Repeatable patterns of behavior in order to connect actors in a given } \\
\text { context. Projected along with the work process or emerging } \\
\text { independently, as long as actors find more effective ways of performing } \\
\text { their tasks. Represent the execution of the work structure. } \\
\text { - Routines keep the organizations committed to providing goods and } \\
\text { services, and they are sustained over the pass of time, explaining this way } \\
\text { how organizations work. } \\
\text { - Routines are learned behaviors, which can be designed along the work } \\
\text { process or arise independently, as individuals find more effective ways to } \\
\text { perform their activities. } \\
\text { - Processes encompass all the capabilities needed to turn inputs into } \\
\text { desired results. This includes specifications, technology, tools, procedures, } \\
\text { policies, practices, and methods. } \\
\text { - Processes provide the structure for work. They refer to the continuous } \\
\text { sequence of facts that happen with some regularity. Once the processes } \\
\text { establish the routines, without those routines, they will cease to exist. }\end{array}$ \\
\hline
\end{tabular}




\section{(Figure 2.2.1 (conclusion)) \\ COMPONENTS AND ORGANIZATIONAL MECHANISMS FOR THE DEVELOPMENT OF ACAP}

\begin{tabular}{|c|c|}
\hline Authors & 3. Mechanisms of learning and knowledge governance \\
\hline $\begin{array}{l}\text { López, Peón, and } \\
\text { Ordás (2005) and } \\
\text { Andreeva and } \\
\text { Chaika (2006) }\end{array}$ & $\begin{array}{l}\text { - A set of procedures for acquisition, distribution, and interpretation of } \\
\text { - Enowledge and the register of organizational memory. } \\
\text { impacting outcomes at different levels. } \\
\text { - Make processes of change easy and effective. They emphasize the } \\
\text { multidisciplinary work groups, the establishment of committees, the } \\
\text { delegation of responsibilities, and the intensification of information } \\
\text { exchange among departments as organizational mechanisms. }\end{array}$ \\
\hline
\end{tabular}

Source: Elaborated by the authors.

Based on these elements and organizational mechanisms (behavior and skills of change and innovation, routines and processes of search or innovation and mechanisms of learning and knowledge governance), we will seek to identify their cluster and the mechanisms to support the development of ACAP among the researched organizations.

\section{METHODOLOGICAL PROCEDURES}

In order to meet the objective of the research, the present study was characterized as an empirical research of qualitative approach (Flick, 2009; Creswell, 2010), of exploratory and descriptive nature (Martins \& Theóphilo, 2009). It was carried out through a multiple case study, which investigated in detail three organizations of the metal mechanics segment (Alpha, Beta, and Gamma), through the analysis of the procedures, resources, mechanisms and systems that allow those organizations to develop ACAP, according to the model proposed by Zahra and George (2002).

The segment of metal mechanics was chosen for being a strategic sector regarding the local production matrix and in the region where the research was developed. The companies have successful business trajectories, being considered traditional companies and technological reference in their field. They are all significant regarding market share, and also play a significant role in terms of employment, generation of income, and development of the southern region of Brazil. 
The information was initially collected in the organizations through the analysis of internal documents, such as publicity materials, folders on the companies' evolution story, meeting minutes, printed and online newsletters, social networks and news sites about the respective organizations, in order to constitute the story of each organization in their process of growth and business expansion.

In the second phase of the research, we interviewed the managers suggested by the board of directors, who work in the departments responsible for acquiring, assimilating, transforming, and applying information from the external environment. Therefore, the interviews were conducted with five managers from each of the studied organizations, from creation, development, market, planning, and production areas. All the 15 managers interviewed have worked for at least five years in these companies, and have the power to influence strategic business decisions, playing this way a prominent role in their management.

Regarding ACAP, the following capacities proposed by Zahra and George (2002) were considered: acquisition; assimilation; transformation; and application of knowledge. From this reference, a research instrument was developed with open-ended questions, serving as a guide during data collection.

To analyze data, we opted for the technique of content analysis (Bardin, 2011) for its refined qualitative data analysis. This technique requires diligence, patience, and time from the researcher and it also demands intuition, imagination, and creativity, especially in the definition of the analysis categories. According to Mozzato and Grzybovski (2011), content analysis gains more and more legitimacy in qualitative research in the field of Administration. It has evolved due to its concern with scientific accuracy.

In-depth interviews were the primary data of the research, and the documents analyzed constituted the secondary data. Soon after, all data were organized through content analysis, following the three investigation phases proposed by Bardin (2011): pre-analysis, material exploration and treatment of results, and inference and interpretation.

The first phase of this study analysis consisted of the managers' interviews transcription. Afterwards, the transcripts and documents were read. During the reading, what was considered important by the researcher for the analysis stage was marked out. At the end of each interview, a table systematizing the clipped texts was created. After reading and systematizing all the interviews, the frequency and repetition of words or phrases were verified and a table was drawn up, in order to systematize all the interviews. 
Regarding the use of the material, a priori categories were established, based on the identification of the mechanisms and instruments for the development of dynamic capabilities proposed by Meirelles and Camargo (2014) and used for the development of ACAP. It was considered: 1. behaviors and abilities of change and innovation; 2. routines and processes of search or innovation; 3. learning mechanisms and knowledge governance. The categories of analysis that led to this research are presented in Figure 3.1.

\section{(Figure 3.1)}

TECHNICAL MODEL OF ANALYSIS

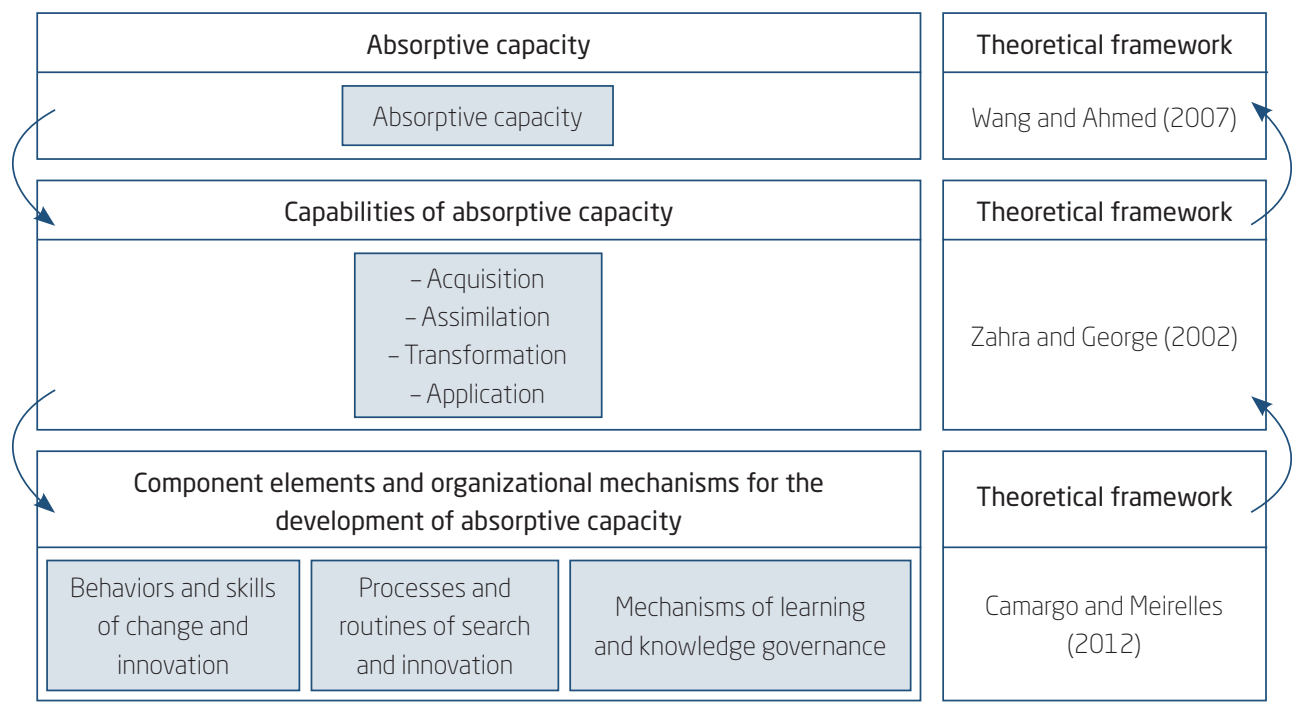

Source: Elaborated by the authors.

Data were processed in the last phase, and the interpretation and conclusion were performed according to defined categories and precategories, in the light of the theoretical framework that guided the present study. Data triangulation technique was used, which occurs when the study takes into account more than one source of evidence (interviews, documents, and theories), aiming to analyze a theme under different points of view to achieve more robust theoretical and empirical contributions.

\section{RESULTS ANALYSIS}

In this section, we present the component elements and organizational mechanisms that support the development of ACAP in each of the analyzed companies. 
Regarding the behavior and skills of change and innovation used by the company Alpha, we highlight: the ability to learn from scientific studies, that means, literature is the ground for the dissemination of internal knowhow, contributing to the development of organizational knowledge in the company. This intangible asset guarantees individual and collective growth of the groups, as well as spread of the best practices. This statement corroborates the studies of Wang and Ahmed (2007), since the authors claim that the employees' abilities to learn faster will bring advantages over competitors. It also addresses Zahra and George (2002), once the capabilities of employees are essential to the evolution of ACAP, especially in the acquisition and assimilation of knowledge.

We use literature as a reference, but the same know-how you must apply inside the company, or buy some external tool. This knowledge is connected to people. Nowadays there is a lot of discussion about it, how we try to structure this question of transforming that cloud, which is knowledge, into an asset and try to keep it somehow protected ... try to keep it within certain limits and not let it completely escape, do not let it go away or it just stays with the person (Product engineering manager).

The ability to interact with customers and among sectors is a strong point in the company, with an intense exchange of information, which favors the development of its ACAP. The contact with the clientele is directly on the field, in order to check the grower's needs. For Alpha, this is the way by means of which better results are brought to the company. Listening to customers is a powerful source of inspiration for improving products and processes. In this way, the feedback can help the company developing strategies faster than the competitors, as Collis (1994) states. Alpha is able to do so, as it can be confirmed in the following reports:

And we have, let's say, that feeling and this relationship with them [clients] of what's going into the market. It's probably the main instrument we use (Commercial manager).

We always try to keep the contact network and to be up to date (Product engineering manager).

In light of these evidence, it can be inferred that the customer-relationship capacity is a relevant factor for the identification of innovations and 
improvements to be performed in the products and services developed. According to Camargo (2012), this organization's relationship capacity turns the expectations and needs of its clients foreseeable, thus contributing to the achievement and the sustainability of competitive advantage in the organization.

It is important to know that this type of information source does not require the organization to have a high level of technological competence. Moreover, reports show that risk-averse companies seek sources already known and usual, which in a way fuels their knowledge base, but not to the point of investing in radical innovations (Zahra \& George, 2002). Therefore, knowing the expectations and needs of the clients can be a way to keep on doing what has always been done.

Also, concerning the behaviors and abilities that propitiate the development of ACAP in the company Alpha, the capacity for solving problems is emphasized. According to Rabechini and Pessôa (2005), skills mean the ability of individuals to solve problems. For Andreeva and Chaika (2006), problem-solving is one of the non-specific skills that allows the organization to act in favor of any kind of change.

In this sense, it can be inferred that Alpha is able to do so because it prioritizes its customers, looking for them in order to identify what the problems are and, then, finding the solutions. This behavior identified in Alpha contributes significantly to the development of ACAP, as evidenced in the following statement:

We are all in the same boat, we go to the customers, and we listen to them. Listening to what they need, which solutions are necessary, or hearing them say: "That would be a solution for our problem" (Commercial manager).

Regarding the previously identified search and innovation routines and processes which enable Alpha company to develop ACAP, the routines of risk management stand out. They analyze events that may occur, negatively or positively influencing an objective, a project and/or a decision taken by the company. For the company, risk management aims to identify and manage multiple risks, seize opportunities, optimize capital, and strengthen decisions. The ability to take risks refers to the ability of the organization to manage its ambitious goals, looking for the mismatch between its ambition and its resources, aiming to use them creatively (Wang \& Ahmed, 2004). In this sense, it can be stated that ACAP's transformation and application 
capabilities are directly related to risks and uncertainties, often requiring scarce resources.

Also noteworthy is the search routine for product information, customers, competitors, and trends. This is habitual in the company, and it has contributed to keeping competitive advantage. This information search is operationalized through the participation in symposiums, seminars, national and international congresses, and technical visits to other companies - all of those being considered the main search sources of the company. This information underpins business decision-making, enhancing performance and enabling the long-term success of the organization

In a complementary sense, Vega-Jurado et al. (2008) explain that the most common sources of information are the so-called "market sources" (competitors, customers, consumers) and others, called "sources of information" (universities, research institutions, congresses), which are relevant to the development of innovative products and important in hightech sectors.

The routines of controlling and monitoring the competition were also evident in the company. Zahra and George (2002) explain that right in the moment of acquisition and assimilation of knowledge, the organization monitors the external environment in order to anticipate changes. Alpha performs the analysis through formal documentation, and the information from this follow-up aids the company in diagnosing the competitors' strengths and weaknesses, as shown in the following excerpt:

We have a document in which we map our main competitors. What their industrial park is, whether they own a single plant or more, whether they have painting or not, whether they do or do not have a complete process. It is formalized. This information helps us evaluate their weaknesses and strengths (Commercial manager).

By monitoring the competition, it is possible to verify the strategies used and to observe possible flaws in their products, making it possible to offer higher quality products or services. From Miller's (2002) perspective, executives recognize that companies compete more effectively when their managers make sound decisions based on an adequate understanding of the potential opportunities and risks of a particular business sector.

Alpha knows that in order to maintain the company's growth, it is important to expose its brand, seek new prospects and business possibilities, while keeping an eye on the competition. By attending fairs, it is possible to observe all these factors at once. The company uses this external information 
source as a way to absorb market information, competitors, suppliers, customers, or new technologies.

That said, it is clear that information search routines implemented by companies allow them to receive external knowledge and also assimilate, transform and apply them in order to obtain competitive advantages (Wang \& Hamed, 2007).

Finally, regarding learning mechanisms, and as a way of disseminating information and knowledge, the research showed that the company makes use of the mechanism of sharing information among its members (Andreeva \& Chaika, 2006). Alpha conducts an internal symposium every two months. This event, which has a predefined calendar, is presented each time by a different department. The chosen department must present relevant themes, relate them with other areas of the company and which activities have been performed. This identified mechanism reinforces the thesis of Andreeva and Chaika (2006). They consider that the existence of multidisciplinary working groups, committees, the delegation of responsibilities, and the intensification of information exchange among departments are all important mechanisms to support the company's capabilities. Zahra and George (2002) emphasize the importance of social integration mechanisms, once they are essential for the assimilation of knowledge. This type of mechanism facilitates the flow of information and how to transform and explore it.

Also noteworthy is the use of technical support as an important learning mechanism. That is, ACAP relies on knowledge transfer within the company, through individual capacity, experienced and responsible professionals (gatekeepers) who are essential in order to sort information, explain it and allow everyone to understand it (Cohen \& Levinthal, 1990).

Technical support assists the organization in making changes to its processes (Camargo, 2012). This mechanism is an alternative for companies to get information from the external environment, which is decisive for the business management of organizations. Alpha is strategically assisted and supported by an economist and other advisors, corroborating aspects related to products and business operation. This technical support used by Alpha assists in the development of its product innovations and productive techniques, therefore contributing to the generation of competitive advantage.

It can be inferred that the company conducts its learning process from how the company deals with its customers and suppliers by getting key business knowledge and a better relationship with them.

It is clear that according to Zollo and Winter's (2002) statement, one way to develop skills, maintaining at the same time competitive advantage, 
is by accumulating knowledge. Thus, the more a company amasses knowledge by expanding its base, the more it will innovate, and the more it innovates, the more it will learn and expands its knowledge. This refers to a recursive relationship between ACAP and innovation.

In this sense, interaction with the external environment is crucial, once it anticipates changes, renews and expands the knowledge base, and invests in innovations.

Beta Company, in turn, also develops ACAP through various component elements and mechanisms. Regarding behaviors and skills of change and innovation, the ability of learning stands out, as it had already happened to Alpha Company. Beta seeks knowledge to implement advancements in its current processes, products, and ways. According to Collis (1994), Meirelles and Camargo (2014), the ability to learn is an instrument to develop capacities.

The company also supports the staff's personal development, by offering them one-week long courses at national level. The company also promotes participation in fairs and events and encourages the staff's professional qualification.

We have sent several employees and collaborators to take courses. These are usually national short courses that last up to one week (Superintendent director).

The company promotes the participation out of the site, in fairs, events, and we stimulate professional qualification (Manufacturing director).

According to Zahra and George (2002), the employees' experience and their level of education predate ACAP. ACAP can be understood as the result of a cumulative process. Thus, the research showed that the investment in courses and training has been a routine in the company, allowing it to seek and to assimilate knowledge. Training is a relevant tool that organizations use to address challenges and to seize potential market opportunities. It can be considered a driving factor for organizational development, as it aims to train and to continually develop people, so that they can learn new applied skills in the continuous improvement of processes and the performance of organizations. The investment in courses and training aims to qualify the team in order to have a more competitive staff.

The capacity of relationship was another behavior and skill identified in Beta. The organization has strong ties with its customers and suppliers and, 
in many cases, the interaction between them happens through visits. This relationship empowers the company to know, to please and to keep their customers, thus increasing its own credibility in the market. Beta Company has this ability, as stated in the following fragment:

New customers, once in a while, meet some other customers of ours, and they happen to recommend each other our product. It is a two-way street, because we are not only looking for new customers, they are also looking for us. That is what we call relationship. [...] There is a quite strong personal relationship from both sides. We have been constantly visited by our suppliers here, and we do like it (Managing director).

Given the evidence presented, it can be inferred that Beta has the capacity of relationship with its customers and suppliers, a relevant factor in identifying innovations and future improvements in the products which are developed. Listening to customers is a powerful source of inspiration for improving products and processes. Feedback is another tool to help the company developing strategies faster than its competitors, as stated by Collis (1994). Also, according to Zahra and George (2002), it is a way to stay in the market through incremental innovation.

In matters of behavior, the ability for problem-solving was also noticed in Beta. By doing so, the company has institutionalized some procedures, such as the use of the Ishikawa diagram. This tool identifies the causes of a problem, observing a possible existence and the localization of bottlenecks (Ishikawa, 1993). The company also uses informal problem-solving practices, like groups meeting informally to discuss some problems. The company searches group solutions, bringing together people who can help to get the solution the company needs.

These findings corroborate the opinion of Andreeva and Chaika (2006), who say problem-solving is one of the non-specific skills to allow organizations to act in favor of any kind of change. It also meets Camargo's (2012) opinion, that discussions, either formal or informal, among collaborators during meetings, favor the resolution of various types of problems. Zahra and George (2002) explain that companies do not always promote the integration of knowledge, although the sharing of knowledge facilitates its transformation and exploitation.

The routines and the processes of search and innovation identified in Beta are similar to those identified in Alpha: routines of information searching, controlling and monitoring competitors, and managing risks. 
The information search routine happens with the participation in national and international fairs, in the company's own clients and other companies, especially when it comes to investments, clients, trends, and studies carried out in the segment. This process ensures improvement, placing the company in a more competitive way, in a market that demands fast action and decisions. Zahra and George (2002) explain that companies who obtain knowledge from a number of sources, plus the diversity of these sources, influence the capabilities of acquisition and assimilation significantly.

During its process of knowledge intake, the company carries out the study of processes and products, aiming by this to perform modifications and innovations whenever needed. The action of learning in the organization happens through the exchange of information with clients, work groups, research, and other companies. This education is fundamental, because, through it, the company can grow and develop effectively to achieve positive results.

This exchange of experiences has allowed Beta to boost its knowledge in order to develop new ideas or improve its internal processes, therefore assisting the company in the process of establishing innovations.

The monitoring of the competition is often performed in order to identify opportunities and threats. Beta continually controls and monitors its competitors by: attending trade shows, failed negotiations, the Internet, profile analysis, and cross-checking, in order to verify the veracity of information.

This is a continuous movement throughout the year (Managing director).

And I have this habit that, every time the competitor outperforms me, my field manager makes a checklist to see why the work was won by the competitor. So we can measure if they are doing something different and we give feedback to our engineering (Commercial manager).

By monitoring the competition, it is possible to verify the strategies used, observe possible flaws in the competitors' products and, thus, market higher quality products or services. From Miller's (2002) perspective, executives recognize that the companies compete more effectively when their managers make sound decisions based on an adequate understanding of the potential opportunities and risks of a particular business sector. 
Still, regarding the search and innovation routines and processes, Beta performs risk management in all its activities, analyzing the events that may occur, and if they will positively or negatively influence a project, an objective or a decision. In this way, the company improves the decision-making process by raising the confidence level, once the company has more peace of mind.

In order to develop Beta's ACAP, Industrial Benchmarking becomes a quintessential mechanism of support. This mechanism aids the organization to assimilate relevant knowledge and technologies from other organizations of the same sector (Camisón \& Forés, 2010). Industrial Benchmarking is a predecessor of ACAP and a mechanism to assist its development. Beta also pays visits to other non-competitor companies, national and foreign ones, searching for ideas and models to be implemented in the organization. By visiting other companies, Beta can identify new materials, technologies, or ideas to be implemented in the company in order to help the development of new products. This mechanism corroborates the thoughts of Oliveira (2016), who claims that informal interactions with other organizations can also contribute to the identification and acquisition of new information.

As a way of spreading information and knowledge, the research showed that the company uses both the sharing of information and learning mechanisms, along with knowledge governance, for the sharing of information among the organization's members. The meetings, the emails, and the company's information system are all used by Beta to share pertinent information.

We share information by emails, and often in our meetings (Managing director).

Much of the information shared is on the network, the data network has access levels, there are files, addresses, and these addresses have authorization levels (Quality manager).

It can be inferred that companies care about the interaction among sectors, making sure knowledge is transmitted to all team members. Like Alpha, Beta makes use of technical and strategic support mechanisms, and the company is helped by an outsourced company in order to promote improvements in its system of information. The company is also backed up by consultancies, advisors, and universities, whenever needed. Technical support assists the organization in making changes to its processes (Camargo, 2012). This mechanism also refers to an alternative for companies to absorb 
information from the external environment, something decisive for the business management of such small level organizations.

Finally, Gama also develops ACAP through various component elements and mechanisms. Regarding behaviors and skills, the company also stands out for its relationship skills. The institution values its good relationship with customers and suppliers. The bond of trust with customers brings many benefits to the company, as well as valuable information, which contributes to foster customer's loyalty, increasing the credibility of the organization in the market. Regarding the suppliers, this relationship provides product diversity, good payment conditions, and business partnership.

We hear our suppliers and our customers. It's very rich information (Marketing manager).

The partnership, the relationship, result in the upcoming of new, good things to the company (Industrial director).

The relationship skills make it easier for the company to learn the needs of customers, incrementally innovating products (Zahra \& George, 2002). In addition, the relationship capacity among employees brings about a peaceful exchange of ideas and information, which helps the finding of solutions (Camargo, 2012), allowing for the existence of the recursive learning cycle, touted by Zollo and Winter (2002), which increasingly helps the company in the development of its ACAP.

It also shows the possibility of personnel's qualification, operated through financial aid in postgraduate courses (master degrees and specializations), specific courses, and foreign language courses. It is noteworthy that ACAP depends on the level of training, education, and experience of employees, so the relationship with the ability to assimilate and apply knowledge results positive.

We invest in the employee (Industrial director).

The company sponsors with some percentage of master degrees, MBAs, also specialization courses, specific courses, English courses (Business director).

Also noteworthy is the company's ability to solve problems, a kind of pattern behavior on the investigated companies. For Gama, solving customer's problems is crucial to business competitiveness. Thus, it can be 
argued that problem-solving is related to ACAP's ability to assimilate, creating new knowledge for innovation (Zahra \& George, 2002): "The clients want you to solve their problems. And our beginning was the same. Either we dominated this package, or we would be dead. And it worked very well" (Industrial director).

Regarding the routines and processes, like the other companies, Gama constantly monitors the market and seeks information over products, customers, competitors, and trends. In this task, networks, sales representatives, salespeople, customers, and fairs support Gama in the finding of information. This follow-up complements the organization's strategic management by enabling quick actions and decisions in face of constant market changes, essential for incremental and radical innovation (Zahra \& George, 2002). Identifying and capitalizing on market opportunities, as well as recognizing the value of external information, assimilating and applying it commercially, are some aspects identified by Meirelles and Camargo (2014) as consistent with ACAP.

It was also perceived the company's ability in the application of knowledge, which is relevant concerning quickly responding to environmental variations. In the most affected sectors by rapid and constant change, companies' competitive advantage derives from their ability to adapt to the environment (Teece et al., 1997). This task is directly linked to people, as the company values its human capital and knows the importance of being resilient in an ever-changing environment.

Risk management routine was also observed in the company. Gama manages risk management through meetings. On such occasions, they evaluate scenarios and turnover perspectives.

We take risks for opportunities. Risk management is performed, though. Simply put, we have a meeting and we evaluate it. Then, it is worked upon, scenarios are envisioned. What are you going to do, what our turnover will be like, and so on (Business director).

Gama performs risk management by evaluating scenarios, turnover perspectives, among others. This routine allows the controlling of: acceptable risks, capital, pricing and customer portfolio management, thus adding value to the organization. Therefore, it is understood that this routine influences the transformation and the application of ACAP knowledge.

Eisenhardt and Martin (2000), Winter (2003), and Teece (2009) argue that organizational routines represent one of the pillars of organizational capacity. Routines provide support in the achievement of results. 
A relevant aspect observed in Gama, from the perspective of learning mechanisms and knowledge governance causing the development of ACAP, refers to research cooperation in partnership with universities, where the company participates in a pioneer project on precision agriculture. Information from research is essential for the development of the organization, and the attainment of good results. This learning mechanism identified in Gama corroborates with Murovec and Prodan (2009), who state that innovation-related activities carried out with different types of partners (suppliers, customers, competitors, consultants, and universities) can increase the organization's ability to transfer relevant information and tacit knowledge. Sources of scientific information can generate highly original products (radical innovation). Actually, they are complex knowledge, quite often not found in the company's knowledge base (Zahra \& George, 2002).

The company also has the following mechanisms: industrial benchmarking, capacity to cooperate with research, capacity to interact with customers, research capacity, company acquisition, and technical support identified and described in the analysis of the other companies.

The acquisition mechanism of the company, according to Camargo (2012), is a mechanism in which the company acquires knowledge and skills through the buyout of other companies. According to Cohen and Levinthal (1990), taking over an organization has a positive effect on ACAP in all its dimensions. Gama's purpose was to use its know-how:

The company eventually purchased a company some time ago. It was for sale and Gama acquired it. I had no interest in keeping that name on the market, I just brought the engineers in, I bought the brain of that company, let's say (Industrial director).

In this sense, the company learning process happens due to a number of reasons: customers, company buyout, research, partnerships with other companies, employees, and competitors. This expansion of knowledge can generate new knowledge, or at least improves it. Whenever it is applied for the benefit of the organization, it becomes a competitive advantage.

In a nutshell: the capacity to engage with customers, suppliers, and among the company's sectors, plus the ability to learn from customers, competitors, internal groups, from products and processes, all these behaviors and skills for change and innovation were the highlights in the surveyed organizations. 
Regarding processes and routines of search and innovation, what stands out is: risk management; the search for market information; monitoring the competition; and the investigation of knowledge.

Finally, regarding learning mechanisms and knowledge governance, the following procedures turn up: learning by exchanging information with customers, suppliers, and internal working groups; the organizations' takeover; research partnerships with external institutions; and the development of internal research.

\section{FINAL CONSIDERATIONS, LIMITATIONS, AND SUGGESTIONS FOR FUTURE STUDIES}

This research aimed to understand how the development of ACAP occurs in a group of companies operating in the sector of metal mechanics, located in the south of Brazil, through the identification of their behaviors and skills, routines and processes, the mechanisms of learning and knowledge governance. In order to achieve this objective, the model of dynamic capacity development presented by Meirelles and Camargo (2014) was used with the delimitation of the absorptive capacity and, more specifically, the model proposed by Zahra and George (2002).

With the results obtained in this study, it is clear that Alpha, Beta, and Gama have similarities in some component elements and organizational mechanisms for the development of ACAP, such as: risk management; continuous search for market information, and; valorization of the good relationship with customers and suppliers.

On the other hand, differences were also observed when it comes to learning. In Alpha, for example, learning happens at the group level; in Beta by means of products and processes; and in Gama through customers and competitors. They also differ in their learning mechanisms and knowledge governance. Alpha focuses on the positioning with customers and suppliers; Beta on learning through information exchange with clients, workgroups, research, and other companies; and Gama learns by taking over companies, and by researching with its customers, partners, and their own employees.

However, competitive advantages achieved by the companies analyzed in this research were acquired and developed through certain capabilities which, in turn, were composed of a mix of behaviors and skills of change and innovation, routines and processes of search or innovation, and mechanisms of learning and knowledge governance. These elements turn 
these organizations more competitive in a turbulent and dynamic business environment. Among the three organizations investigated, Gama stands out for cultivating more consistently the components and organizational mechanisms for ACAP development, related to people's management, to the informality of organizational routines and processes, and to the entrepreneurial posture of its leaders.

As a theoretical contribution to the strategic area, this research showed that there is a very close relationship between ACAP (Cohen \& Levinthal, 1990; Zahra \& George, 2002) and the instruments and mechanisms for developing this capability, reinforcing the studies of Wang and Ahmed (2007) and Meirelles and Camargo (2014). We highlight the contribution of ACAP to the study, as it explored the relevant antecedents pointed out in the literature.

Regarding its managerial contribution, the study presented a structure of operationalization of the ACAP construct in a group of companies, in order to understand which are the management instruments and mechanisms that underpin the development of acquisition, assimilation, transformation, and application of knowledge as a way to achieve better results for competitiveness. Thus, it is expected that this study helps companies' managers in the metal mechanics sector maximizing their results by applying mechanisms and instruments to develop ACAP identified in this research, contributing to the implementation of new products or services for their clients.

It is understood that this study has its limitations, which is something common in research work. Among the limitations of this study, there are two points that deserve consideration: 1 . the conclusions are restricted to the perceptions of managers, once other audiences were not taken into account in the analysis of mechanisms and instruments of ACAP development; 2. the application of the research was restricted to the metal mechanics sector. Therefore, any conclusions must be limited to the specifics of this sector.

Being aware of such limitations, we suggest comparative studies among organizations that operate in different segments, in order to allow a better understanding of the variables and how they connect with the theme. Due to the cumulative trait of ACAP, it is important to carry out longitudinal studies, in order to highlight the effect of these mechanisms throughout the life cycle of organizations.

Despite the limitations presented, this study represents a breakthrough in pointing out the mechanisms and instruments supporting the development 
of ACAP in companies in the metal mechanics sector, contributing to the development of new products, the generation of new jobs and the generation of income in this sector. In a broader sense, the study aims to strengthen the regional development.

\section{CAPACIDADE ABSORTIVA: ELEMENTOS COMPONENTES E MECANISMOS ORGANIZACIONAIS DE SEU DESENVOLVIMENTO}

\section{RESUMO}

Objetivo: O objetivo deste estudo constituiu-se em compreender como ocorre o processo de desenvolvimento de capacidade absortiva (ACAP) de um conjunto de empresas que operam no setor metal mecânico, instaladas na Região Sul do Brasil, por meio da análise dos seus comportamentos e habilidades, das rotinas e dos processos, e dos mecanismos de aprendizagem e governança do conhecimento.

Originalidade/valor: A relevância consiste na operacionalização dos elementos componentes e mecanismos organizacionais de desenvolvimento de capacidade dinâmica (Meirelles \& Camargo, 2014), como forma de desenvolvimento de ACAP (Wang \& Ahmed, 2007) em organizações pertencentes ao setor metal mecânico.

Design/metodologia/abordagem: Caracteriza-se como uma pesquisa empírica de abordagem qualitativa, de natureza exploratória e descritiva, realizada por meio de estudo de casos múltiplos, buscando investigar detalhadamente três organizações do segmento metal mecânico, por meio da análise dos procedimentos, recursos, mecanismos e sistemas que lhes permitem desenvolver a ACAP. Os dados foram analisados por intermédio da análise de conteúdo.

Resultados: Foi possível inferir que as empresas investigadas desenvolvem a ACAP por intermédio de comportamentos e habilidades, como capacidade de relacionamento, capacidade de aprender e capacidade de desenvolver pessoas, bem como por meio de rotinas e processos, destacando-se rotinas de busca de informações, rotinas de monitorar o mercado e gestão de riscos, e ainda mediante mecanismos 
de aprendizagem e governança do conhecimento, como pesquisas, trocas de informações entre clientes e fornecedores e outras empresas.

\section{PALAVRAS-CHAVE}

Capacidades dinâmicas. Capacidade absortiva. Vantagem competitiva. Metal mecânico. Mecanismos organizacionais.

\section{REFERENCES}

Andreeva, T., \& Chaika, V. (2006). Dynamic capabilities: What they need to be dynamic? [Working Paper, 10 (E)] Saint Petersburg State University, Saint Petersburg.

Bardin, L. (2011). Análise de conteúdo. São Paulo: Edições 70.

Breitbach, A. (2004). Comportamento heterogêneo do "complexo metal-mecânico". Carta de Conjuntura FEE, ano 13, (3). Recuperado de http:// carta.fee.tche.br/article/comportamento-heterogeneo-do-complexometal-mecanico/

Burcharth, A. L. L. de A., Lettl, C., \& Ulhøi, J. P. (2015). Extending organizational antecedents of absorptive capacity: Organizational characteristics that encourage experimentation. Technological Forecasting and Social Change, 90, 269-284. doi:10.1016/j.techfore.2013.12.024

Bygdas, A. L. (2006). Enacting dynamic capabilities in distributed organizational environments. Proceedings of the EGOS Conference, Bergen, Norway, 22.

Camargo, A. A. B. (2012). Capacidades dinâmicas em uma empresa secular de serviços: $O$ caso Berlitz (Dissertação de mestrado, Universidade Presbiteriana Mackenzie, São Paulo, SP, Brasil).

Camisón, C., \& Forés, B. (2010). Knowledge absorptive capacity: New insights for its conceptualization and measurement. Journal of Business Research, 63(7), 707-715. doi:10.1016/j.jbusres.2009.04.022

Cohen, W. M., \& Levinthal, D. A. (1989). Innovation and learning: The two faces of R\&D. Economic Journal, 99(397), 569-596. doi:10.2307/2233763

Cohen, W. M., \& Levinthal, D. A. (1990). Absorptive capacity: A new perspective on learning an innovation. Administrative Science Quarterly, 35(1), 128-152. doi:10.2307/2393553 
Cohen, W. M., \& Levinthal, D. (1994). Fortune favors the prepared firm. Management Science, 40(2), 227-251. doi:10.1287/mnsc.40.2.227

Collis, D. J. (1994). Research note: How valuable are organizational capabilities? Strategic Management Journal, 15(1), 143-152. doi:10.1002/ smj.4250150910

Creswell, J. W. (2010). Projeto de pesquisa: Métodos qualitativo, quantitativo e misto (3a ed.). Porto Alegre: Artmed.

Dosi, G., Faillo, M., \& Marengo, L. (2008). Organizational capabilities, patterns of knowledge accumulation and governance. Organization, 29(8-9), 1165-1185. doi:10.1177/0170840608094775

Eisenhardt, K. M., \& Martin, A. (2000). Dynamic capabilities: What are they? Strategic Management Journal, 21 (10-11), 1105-1121. doi:10.1002/ 1097-0266

Ferreira, G. C., \& Ferreira, J. J. M. (2017). Absorptive capacity: An analysis in the context of Brazilian family firms. Revista de Administração Mackenzie, 18(1), 174-204.

Flatten, T. C., Engelen, A., Zahra, S. A., \& Brettel, M. (2011). A measure of absorptive capacity: Scale development and validation. European Management Journal, 29(2), 98-116. doi:10.1016/j.emj.2010.11.002

Flick, U. (2009). Introdução à pesquisa qualitativa (3a ed.). (Joice Elias Costa). Porto Alegre: Artmed.

Gerard, J. A. (2011). A theory of organizational routines: development of a topology and identification of contextual determinants. Ann Arbor: ProQuest UMI Dissertation Publishing.

Guerra, R. M. A., Tondolo, V. A. G., \& Camargo, M. E. (2016). O que (ainda) podemos aprender sobre capacidades dinâmicas. Revista Ibero-Americana de Estratégia, 15(1), 44-64. doi:10.5585/ijsm.v15i1.2168

Helfat, C., Finkelstein, S., Mitchell, W., Peteraf, M., Singh, H., Teece, D., \& Winter, S. (2007). Dynamic capabilities: Understanding strategic changes in organizations. Malden: Blackwell.

Instituto Brasileiro de Geografia e Estatística (2016). Recuperado de https:// www.ibge.gov.br

Ishikawa, K. (1993). Controle de qualidade total: À maneira japonesa. Rio de Janeiro: Campus.

Jansen, J. P., Van Den Bosch, F. A. J., \& Volberda, H. W. (2005). Managing potential and realized absorptive capacity: How do organizational antecedents matter? Academy of Management Journal, 6(48), 999-1015. 
Jones, O. (2006). Developing absorptive capacity in mature organizations: The change agent's role. Management Learning, 37(3), 355-376. doi:10.1177/ 1350507606067172

Lane, P. J., Koka, B. R., \& Pathak, S. (2006). The reification of absorptive capacity: A critical review and rejuvenation of the construct. Academy of Management Review, 31 (4), 833-863. doi:10.2307/20159255

Lane, P. J., \& Lubatkin, M. (1998). Relative absorptive capacity and interorganizational learning. Strategic Management Journal, 19(15), 461-477.

López, S. P., Peón, J. M. M., \& Ordás, C. J. V. (2005). Organizational learning as a determining factor in business performance. The Learning Organization, 3, 227-245.

Majumdar, S. K. (2000). Sluggisn giants, sticky cultures, and dynamic capability transformation. Journal of Business Venturing, 15(1), 59-78. doi:10.1016/S0883-9026(98)00010-X

Martins, G. A., Theóphilo, C. R. (2009). Metodologia da investigação científica para ciências sociais aplicadas (2a ed.). São Paulo: Atlas.

Mathiassen, L., \& Vainio, A. M. (2007). Dynamic capabilities in small software firms: A sense-and-respond approach. IEEE Transactions on Engineering Management, 54(3), 522-538. doi:10.1109/TEM.2007.900782

McKelvie, A., \& Davidson, P. (2009). From resource base to dynamic capabilities: An investigation of new firms. British Journal of Management, 20(1), 63-80. doi:10.1111/j.1467-8551.2008.00613.x

Meirelles, D. S., \& Camargo, A. A. B. (2014). Capacidades dinâmicas: O que são e como identificá-las? RAC, 18, 41-64. doi:10.1590/19827849rac 20141289

Miller, J. P. (2002). O milênio da inteligência competitiva. Porto Alegre: Bookman.

Mozzato, A. R., \& Grzybovski, D. (2011). Análise de conteúdo como técnica de análise de dados qualitativos no campo da Administração: Potencial e desafios. Revista de Administração Contemporânea, 15(4), 731-747.

Murovec, N., \& Prodan, I. (2009). Absorptive capacity, its determinants, and influence o innovation output: Cross-cultural validation of the structural model. Technovation, 29(12), 859-872.

Nelson, R. R. (2009). Routines as technologies and as organizational capabilities. In M. C. Becker \& L. Nathalie. Organizational routines: Advancing empirical research (pp. 11-44). Cheltenham: Edward Elgar.

Nelson, R. R., \& Winter, S. G. (1982). An evolutionary theory of economic change. Cambridge: Belknap Press. 
Oliveira, D. M. L. (2016). Mensuração da capacidade absortiva: Proposta e validação de fatores de mensuração para organizações intensivas em conhecimento de Minas Gerais (Dissertação de Mestrado, Pontifícia Universidade Católica de Minas Gerais, Belo Horizonte, MG, Brasil).

Rabechini R., Jr., \& Pessôa, M. S. D. P. (2005). Um modelo estruturado de competências e maturidade em gerenciamento de projetos. Produção, 15(1), 34-43. doi:10.1590/S0103-65132005000100004

Sausen, J. O. (2003). Adaptação estratégica organizacional: O caso da Kepler Weber $S / A$. (Série Teses de doutorado, Universidade Regional do Noroeste do Estado do Rio Grande do Sul, Ijuí, RS, Brasil).

Sindicato das Indústrias Metalúrgicas, Mecânicas e de Material Elétrico e Eletrônico do Estado do Rio Grande do Sul (2019). Recuperado de http:// www.sinmetal.com.br

Teece, D. J. (2007). Explicating dynamic capabilities: The nature and microfoundations of (sustainable) enterprise performance. Strategic Management Journal, 28(13), 1319-1350. doi:10.1002/smj.640

Teece, D. J. (2009). Dynamic capabilities \& strategic management. Oxford: Oxford University Press.

Teece, D. J., Pisano, G., \& Shuen, A. (1997). Dynamic capabilities and strategic management. Strategic Management Journal, 18(7), 509-533. doi:10.1002/(SICI) 1097-0266 (199708) 18:7\&lt;509::AID-SMJ882\&gt; 3.0.CO;2-Z

Vega-Jurado, J., Gutiérrez-Gracia, A., \& Fernándes-De-Lucio, I. (2008). Analyzing the determinants of firm's absorptive capacity: Beyond R\&D. $R \& D$ Management, 38(4), 392-405. doi:10.1111/j.1467-9310.2008.00525.x

Wang, C. L., \& Ahmed, P. K. (2004). The development and validation of the organizational innovativeness construct using confirmatory factor analysis. European Journal of Innovation Management, 7(4), 303-313. doi:10.1108/ 1460106041056

Wang, C. L., \& Ahmed, P. K. (2007). Dynamic capabilities: A review and research agenda. International Journal of Management Reviews, 9(1), 31-51. doi:0.1111/j.1468-2370.2007.00201.x

Winter, S. G. (1964). Economic "natural selection" and the theory of the firm. Yale Economic Essays, 4, 225-272.

Winter, S. G. (2003). Understanding dynamic capabilities. Strategic Management Journal, 24(10), 991-995. doi:10.1002/smj.318 
Zahra, S. A., \& George, G. (2002). Absorptive capacity: A review, reconceptualization, and extension. Academy Management Review, 27(2), 185-203. doi:10.2307/4134351

Zollo, M., \& Winter, S. G. (2002). Deliberate learning and the evolution of dynamic capabilities. Organization Science, 13(3), 339-351. doi:10.1287/ orsc.13.3.339.2780

\section{$\int$ AUTHOR NOTES}

Gabriela Cappellari, Departamento de Ciências Administrativas, Contábeis, Econômicas e da Comunicação (Dacec), Universidade Regional do Noroeste do Estado do Rio Grande do Sul (Unijuí); Clarice V. N. Welter, Departamento de Ciências Administrativas, Contábeis, Econômicas e da Comunicação (Dacec), Universidade Regional do Noroeste do Estado do Rio Grande do Sul (Unijuí); Lisiane C. R. Hermes, Departamento de Ciências Administrativas, Contábeis, Econômicas e da Comunicação (Dacec), Universidade Regional do Noroeste do Estado do Rio Grande do Sul (Unijuí); Jorge O. Sausen, Programa de Pós-Graduação em Engenharia de Produção (PPGEP), Universidade Federal de Santa Catarina (UFSC).

Gabriela Cappellari is now professor at the Business Department of Universidade Federal do Pampa (Unipampa); Clarice V. N. Welter is now military of the $3^{\text {a }}$ Divisão de Exército Brasileiro; Lisiane C. R. Hermes is now professor at the Faculdade de Artes e Comunicação (FAC) of Universidade de Passo Fundo (UPF); and Jorge O. Sausen is now full professor at the Departamento de Ciências Administrativas, Contábeis, Econômicas e da Comunicação (Dacec) of Universidade Regional do Noroeste do Estado do Rio Grande do Sul (Unijuí).

Correspondence concerning this article should be addressed to Clarice V. N. Welter, Rua Doutor Bozzano, 15, Nossa Senhora de Fátima, Santa Maria, Rio Grande do Sul, Brazil, CEP 97015-000. E-mail: clarice_vepo@hotmail.com

\section{EDITORIAL BOARD}

Editors-in-chief Janette Brunstein

Silvia Marcia Russi de Domênico

Associated Editor

Glória Charão Ferreira

Technical Support

Vitória Batista Santos Silva

\section{EDITORIAL PRODUCTION}

Publishing Coordination

Jéssica Dametta

Language Editor

Daniel de Almeida Leão
Layout Designer

Emap

Graphic Designer

Libro 